\title{
STRUCTURAL ORGANIZATION OF THE OLFACTORY EPITHELIUM OF A SPOTTED SNAKEHEAD FISH, CHANNA PUNCTATUS
}

\author{
Dipak K. MANDAL*, Debraj ROY, Leena GHOSH \\ Department of Zoology, Visva-Bharati University, Santiniketan, West Bengal, India
}

\begin{abstract}
Mandal D.K., Roy D., Ghosh L., 2005. Structural organization of the olfactory epithelium of a spotted snakehead fish, Channa punctatus. Acta Ichthyol. Piscat. 35 (1): 45-50.

Background. Enormous diversities exist regarding shape, number, and arrangement of the olfactory lamellae, distribution of the sensory and non-sensory epithelium as well as the abundance of various receptor cells among different teleosts. This study was aimed at describing the morphology, histology and SEM ultrastructure of the olfactory epithelium of a spotted snakehead fish, Channa punctatus (Bloch, 1793).

Materials and methods. OE of $C$. punctatus was examined through LM and SEM.

Results. Olfactory epithelium of $C$. punctatus containing 18 to 20 lamellae provides a large surface area. Sensory epithelium possesses both ciliated and microvillous olfactory receptor cells (ORC), which are intermingled and distributed throughout the epithelium. ORCs are arranged in alternate rows with supporting cells (SCs). ORC is columnar cell with a round cell body, an axonal process and a long dendrite. The apical surfaces of the ORCs are provided either with 10-12 cilia or numerous microvilli and the SCs with fingerprint like microridges. ORCs with rod-shaped dendrite ending were found in small numbers. Non-sensory epithelium is composed of ciliated nonsensory cells (cNSC) and covered with a dense carpet of cilia, which help in ventilating the olfactory chambers. Conclusions. A large surface area of $\mathrm{OE}$, the high density of both ciliated and microvillous ORC and adequate arrangement for ventilating the olfactory chambers indicate that $C$. punctatus is very much dependent on its olfactory sense.
\end{abstract}

Key words: fish, morpho-histology, SEM, olfactory epithelium, Channa punctatus

\section{INTRODUCTION}

Olfaction plays a vital role in fish life by involving in the various behaviours including food searching, migration, predator avoidance, and reproduction (Hara 1975, 1992). In fish, olfactory receptor organ is represented by the olfactory epithelium situated on the floor of nasal chamber. Many reports are available on the morpho-histology (Zeiske et al. 1987, Hara and Zielinski 1989, Hara et al. 1993) and SEM study (Bannister 1965, Bertmar 1972, Lowe and Macleod 1974, Fisher et al. 1984, Hansen and Finger 2000, Mana and Kawamura 2003) of the olfactory organ of different teleosts. Studies revealed that enormous diversities exit regarding shape, number, and arrangement of the olfactory lamellae, distribution of the sensory and non-sensory epithelium as well as the abundance of various receptor cell types in different teleosts. The folding or lamellae of the olfactory epithelium increase the surface area of the epithelium as well as the sensitivities and efficacy of the olfactory organ (Zeiske et al. 1976). The olfactory epithelium can be separated into sensory and non-sensory epithelium. The sensory epithelium exhibits various distribution patterns such as continuous, separated regular- ly by non-sensory epithelium, interspaced irregularly and scattered in islets (Hara 1993). Two types of olfactory receptor cells (ORC) bearing either cilia or microvilli on their apical surface are common in teleosts (Thommesen 1983, Farbman 2000) and a third type of ORC, crypt ORC has been described in a variety of fishes and considered as a common feature in bony fish (Hansen and Finger 2000). Different sensory cells can be considered as different functional and structural entities with different sensitivities to external stimuli (Yamamoto 1982). Thommesen (1983) reported that ciliated ORCs are tuned toward bile salts and microvillous ORC toward amino acids. However, recent electrophysiological studies concluded that ciliated ORC might be termed as generalists, which respond to varying species of odorants including amino acids, bile salts and other odorants whereas microvillous ORC might be called as specialist, which respond specifically to amino acids and nucleotides (Sato and Suzuki 2001, Hansen et al. 2003). In the present study, therefore, an attempt has been taken to describe the morphology, histology and SEM structure of the olfactory epithelium of an economically important spotted snakehead fish, Channa punctatus (Bloch, 1793).

\footnotetext{
* Correspondence: Dr Dipak Kumar Mandal, Department of Zoology, Visva-Bharati University, Santiniketan-731 235, West Bengal, India, phone/fax: 913463 261268, e-mail: mandaldk@sify.com
} 


\section{MATERIALS AND METHODS}

Adult, live spotted snakehead, Channa punctatus, (15 to $20 \mathrm{~cm}$ in length) were procured from local freshwater bodies at Santiniketan, West Bengal, India and brought to laboratory. Fish were measured, weighed, and deeply anaesthetized with MS 222. Olfactory tissues were procured by dissecting the olfactory chamber, measured, weighed, and processed for the histological and scanning electron microscopic (SEM) preparation.

\section{Histological studies}

Intact olfactory tissues were immersed in aqueous Bouin's solution for a period of 20 hours for fixation. Fixed tissues were washed in distilled water repeatedly rinsed in $70 \%$ ethanol and dehydrated through graded series of ethanol followed by acetone and cleared in benzene. The tissues were embedded in paraffin wax of $56-58^{\circ} \mathrm{C}$ under a thermostat vacuum paraffin-embedding bath for a period of $1 \mathrm{~h}$. Serial thin $(4 \mu \mathrm{m})$ sections of the paraffin block of the tissue were obtained using a rotary microtome. The sectioned tissues were stretched on Mayer's albuminised glass slide and stained with eosinhaematoxylin stain. Stained slides were examined and photographed under Olympus BX52 compound microscope. Cells and nuclei were measured by an ocular micrometer.

\section{SEM preparation}

Olfactory tissues were collected carefully from the nasal chambers. After rinsing in 0.1-M phosphate buffer ( $\mathrm{pH}$ 7.4) the tissues were fixed with $2.5 \%$ glutaraldehyde for 24 hours at $4{ }^{\circ} \mathrm{C}$ and post fixed in $1 \% \mathrm{OsO}_{4}$ in $0.1 \mathrm{M}$ phosphate buffer ( $\mathrm{pH}$ 7.4) for 2 hours. Fixed tissues were dehydrated with graded acetone followed by amyl acetate. Dehydrated tissues were dried through critical point drying, gold-coated, and examined under scanning electron microscope, Hitachi S-530.

\section{RESULTS}

Morphology of the olfactory organ

Channa punctatus possesses a pair of olfactory chambers situated dorso-laterally in the snout, anterior to the eyes (Fig. 1). The olfactory chamber is connected with the external environment through two separate nasal apertures. The anterior incurrent aperture opens through a short muscular tube just above the upper jaw while the posterior one opens directly through a slit. The olfactory system of the fish is composed of olfactory rosette (OR), olfactory nerve $(\mathrm{ON})$, olfactory bulb $(\mathrm{OB})$, and olfactory lobe of forebrain. Olfactory rosettes (OR) are situated on the floor of nasal chambers. The OR is oval in shape, measuring 0.4 to $0.6 \mathrm{~mm}$ in diameter and possesses $18-20$ crescent-shape olfactory lamellae (OL), which are arranged parallel to each other in rostro-caudal orientation (Fig. 2). A long olfactory nerve (1.3-1.5 mm) connects the OR with the olfactory bulb situated nearer to the olfactory lobe of forebrain.
Histology of olfactory epithelium

Olfactory epithelium (OE) of Channa punctatus is a continuous thick sheet $(30-40 \mu \mathrm{m})$ of pseudo-stratified columnar epithelial cells, which is folded to form olfactory lamellae. In lamellae, the epithelium encloses a central lumen called central core, which contains blood vessels, connective tissues and nerve fibres. Central core and $\mathrm{OE}$ are separated by a basal lamina (Fig. 3). The OE is separated into sensory and non-sensory regions, which are irregularly interspaced. The sensory epithelium is composed of columnar ciliated and non-ciliated olfactory receptor cells, columnar supporting cells, and round basal cells. Supporting cells and receptor cells are arranged in alternate rows and the basal cells are situated at the base of the epithelium just above the basal lamina (Fig. 4). Tip of the lamellae contains stratified round to cubical nonsensory epidermal cells, basal cells and mucus-secreting cells (Fig. 5). Non-sensory epithelium is made up with columnar ciliated non-sensory cells, basal cells and mucous cells (Fig. 6).

\section{Cell types in olfactory epithelium}

1) Ciliated olfactory receptor cells (cORC): cORC are columnar, $25.2 \pm 1.54 \mu \mathrm{m}$ in length, bipolar cells bearing a cell body, a long dendrite with 10-12 cilia and an axonal process toward the basal lamina. The cell body containing a round prominent nucleus is situated deep in the epithelium. The cytoplasm is highly granular and takes deep stain (Fig. 4).

2) Microvillous olfactory receptor cells (mORC): mORC are columnar, $17.8 \pm 1.42 \mu \mathrm{m}$ in length, bipolar cells with a long dendrite but without cilia. The cell body is more superficial in the epithelium than the cORC and possesses a round nucleus. Cytoplasm is granular and stains deeply (Fig. 4).

3) Supporting cells (SC): Supporting cells are elliptical to columnar in shape $15.2 \pm 0.84 \mu \mathrm{m}$ in length with prominent central basophilic nucleus situated superficially in the epithelium and without dendrite and axonal process. Cytoplasm is less granular and faintly stained (Fig. 4).

4) Ciliated Non-sensory cells (cNSC): Ciliated non-sensory cells are columnar, $15.07 \pm 2.5 \mu \mathrm{m}$ in length, broad without dendrite and axon and consist of numerous long cilia $(8-8.5 \mu \mathrm{m})$ at its surface. The nucleus is round and located in the middle of the cell (Fig. 6).

5) Epidermal cells (EC): EC are stratified, small (8-9 $\mu \mathrm{m}$ in diameter), elliptical to round in shape with a prominent central nucleus (Fig. 5).

6) Basal cells (BC): BC are small $(6.66 \pm 0.66 \mu \mathrm{m})$, oval in shape with a prominent round central nucleus lying in the deeper part of the epithelium just above the basal lamina (Figs. 4, 5, 6).

7) Mucous cells (MC): Mucous cells are large (30-50 $\mu \mathrm{m}$ in diameter), oval glandular cells are found along with the sensory and non-sensory epithelium (Fig. 5). 

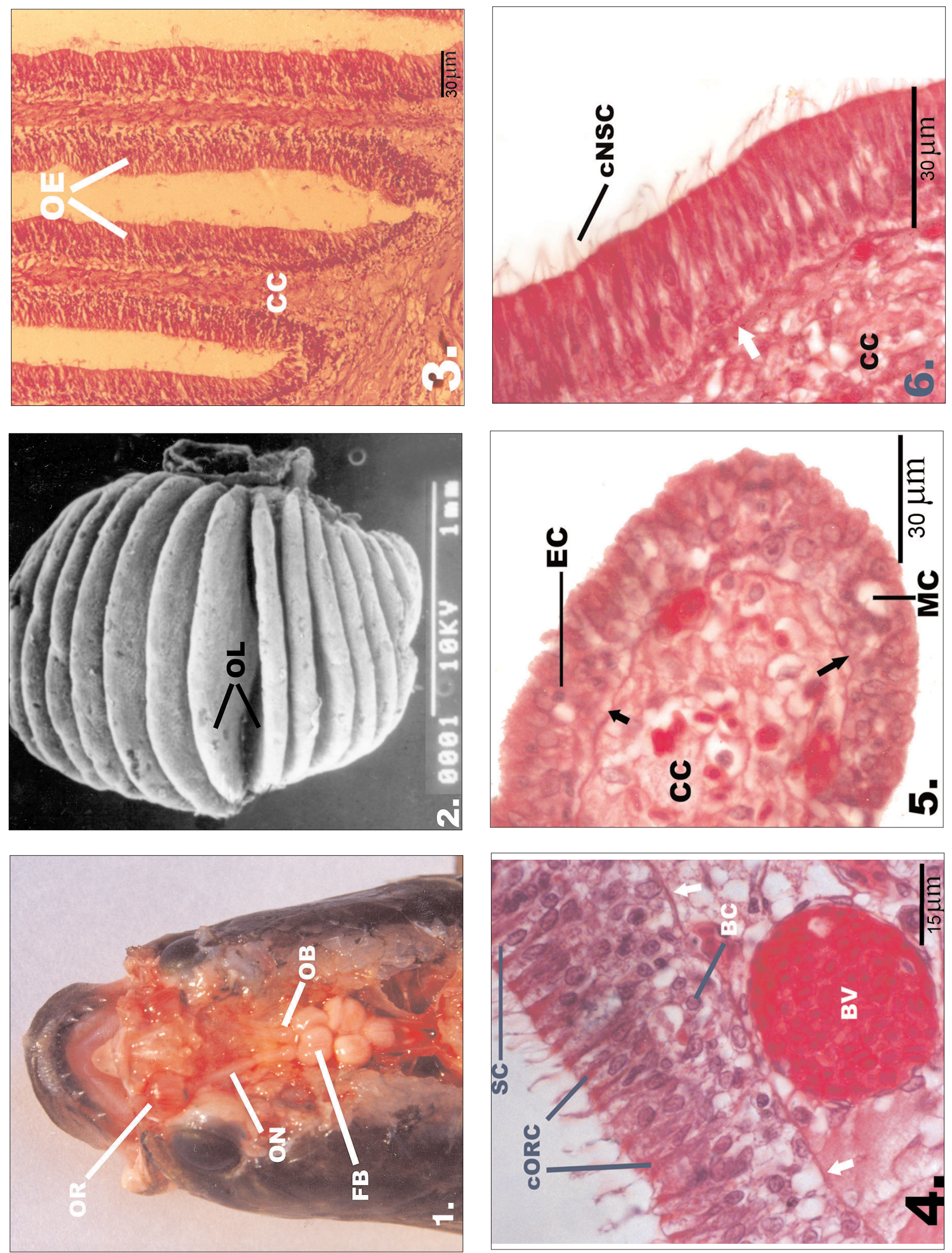

Figs. 1-6. Morphology and histology of the olfactory organ of spotted snakehead fish, Channa punctatus. Fig. 1. Dissected head of $C$. punctatus showing, olfactory rosette (OR), olfactory nerve $(\mathrm{ON})$, olfactory bulb $(\mathrm{OB})$, and olfactory lobe of forebrain (FB). Fig. 2. Olfactory rosette with olfactory lamellae $(\mathrm{OL})$. Figs 3-6. Olfactory rosette $(\mathrm{H}+\mathrm{E})$. Fig. 3. Olfactory lamellae showing olfactory epithelium (OE), central core (CC) separated by basal lamina. Fig. 4. Sensory OE showing the olfactory receptor cells (ORC) and supporting cells (SC) arranged in alternate rows; BC, basal cells (arrows); BV, blood vessel. Fig. 5. Tip of lamella; EC, stratified epidermal cells; MC, mucus-secreting cells; CC, central core. Fig. 6. Ciliated non-sensory epithelium showing numerous columnar ciliated non-sensory cells (cNSC); cc, central core 

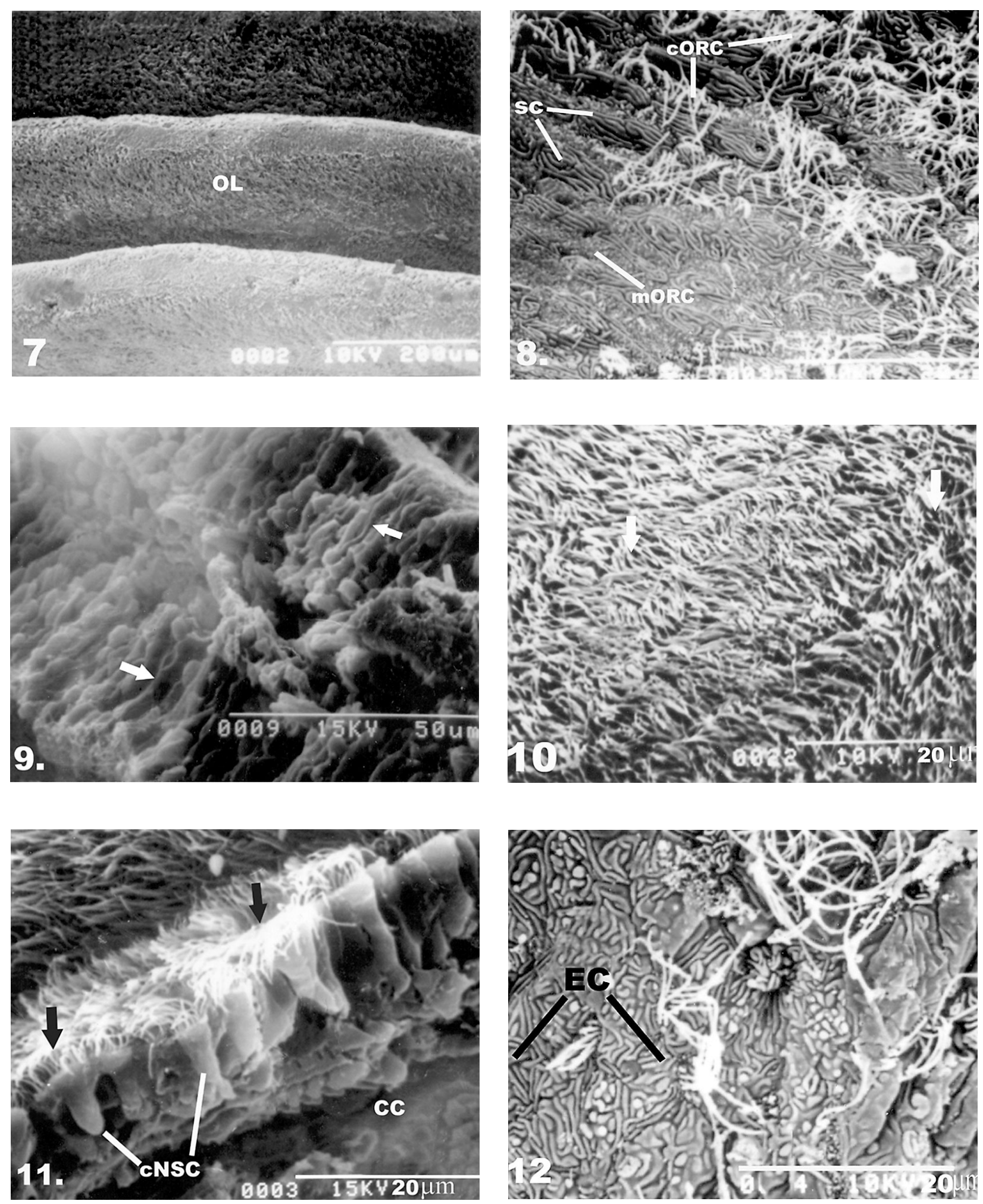

Figs. 7-12. Scanning Electron Microscopic photomicrographs of the olfactory epithelium (OE) of Channa punctatus. Fig. 7. Apical surface of OE on olfactory lamellae (OL). Fig. 8. Surface of sensory epithelium showing ciliated olfactory receptor cells (cORC) with long cilia, microvillous olfactory receptor cells $(\mathrm{mORC})$ with numerous microvilli and supporting cells (SC) with fingerprint like microridges; note that SC and ORC and arranged in alternate rows; scale bar $=20 \mu \mathrm{m}$. Fig. 9. Inner view of sensory epithelium showing the ORC with round cells body (arrow), long dendrite extended to the surface and an axonal process. Fig. 10. Apical surface of ciliated non-sensory epithelium covered with dense carpet of cilia (arrows). Fig. 11. Inner view of ciliated non-sensory epithelium showing columnar ciliated non-sensory cells (cNSC) containing numerous long cilia (arrows) at their apical surface; CC, central core. Fig. 12. Epidermal cells (EC) showing zig-zag pattern microridges at their apical surface 
SEM structure of olfactory epithelium

The olfactory epithelium of Channa punctatus covers the olfactory lamellae (Fig. 7) and is composed of two distinct regions of non-sensory and sensory epithelium. The sensory epithelium is composed of olfactory receptor cells (ORC) and supporting cells (SC) arranged in alternate rows (Fig. 8). The apical surface of the supporting cells is broad, flat, and provided with fingerprint-like microridges. The ORCs are of two types microvillous and ciliated ORC, which are intermingled and distributed throughout the olfactory epithelium. The apical surface of the ciliated ORC is exposed as small round olfactory knob and provided with 10-12 long cilia while the apical surface of the microvillous ORC is broad and consists of numerous microvilli. Another type of ORC with rod shaped dendrite ending is found in small numbers. The sectional view of the sensory area exhibits that ORC is in columnar with a round cell body in the deep of the epithelium, a long, narrow dendrite extended to the surface and an axonal process toward the basal lamina (Fig. 9). Non-sensory epithelium shows a dense mat of cilia of ciliated NSC (Fig. 10) and the sectional view revealed that ciliated NSC is club shaped columnar cell provided with 150-200 long cilia at its apical surface (Fig. 11). Apical surface of epidermal cell is broad, flat and provided with zigzag pattern microridges (Fig. 12). Many mucous cell openings have been observed throughout the epithelium.

\section{DISCUSSION}

Olfactory system is a major chemosensory system in fish and plays an important role in fish life by involving in food searching, migration, predator avoidance, and reproductive activities. The present study describes the gross morphology, histology, and ultrastructure of the olfactory epithelium of a spotted snakehead fish, Channa punctatus. Adequate ventilation is necessary to bring the odorants in the olfactory chamber for perceiving the chemical signals (Kapoor and Ojha 1972, Døving et al. 1977, Belanger et al. 2003). Findings of other authors suggest that ventilation of the olfactory chamber takes place by either forward motion of the fish, hydraulic pumping of the olfactory sac, or by synchronous beating of cilia of ciliated non-sensory cells (Hara 1993). Since the non-sensory epithelium in Channa punctatus is covered with a dense mat of cilia it is highly probable that the ventilation of the olfactory chamber in this fish is achieved due to beating action of cilia of ciliated non-sensory cells. The narrow passage of muscular tube in the anterior nasal aperture prevents the large particles to enter the nasal chamber.

Olfactory epithelium is located in the floor nasal chambers and often folded to form lamellae (Hara 1975). The number, shape and arrangement of the lamellae vary considerably among different teleosts ranging from flat unfolded surface to multi-lamellar rosette (Yamamoto 1982, Zeiske et al. 1992). The large surface area provided by the olfactory lamellae increases the sensitivity and efficacy of the olfactory system (Zeiske et al. 1976). Generally lamellae are arranged laterally around the cen- tral raphe. However, in C. punctatus olfactory lamellae are arranged at the top of the raphe, parallel to each other and in rostro-caudal orientation and provide a large surface area. Two morphologically distinct types of ORC, ciliated and microvillar ORCs are common in teleosts (Zielinski and Hara 1988). They occur together but in different proportions in different species (Zeiske et al. 2003). Erickson and Caprio (1984) observed in catfish that the density of the microvillous ORC was the highest in the medial part of the lamellae while the density of the ciliated ORC was the highest in the lateral areas of the lamellae. Another type of ORC, crypt ORC has recently been discovered (Hansen and Finger 2000). The olfactory epithelium of Channa punctatus possesses both ciliated and microvillous ORC which are intermingled and distributed throughout the epithelium. However, crypt receptor cells are not detected in our study. Microvillous ORCs are dominant over the ciliated receptor cells. The ORC with rod-like distal process has been described in some species (Bannister 1965, Ichikawa and Ueda 1977, Muller and Marc 1984). We also found a few ORC with rod-shaped dendrite ending distributed randomly in the epithelium. Occurrence of the rodshaped olfactory neuron has been observed in the presence of a new physiological condition (Hernádi 1993). Columnar supporting cells form a mosaic interspaced between the sensory receptor cells and are provided with fingerprint-like microridges on their apical surface that help in holding mucous film over the epithelium and in protecting the sensory cells from mechanical injury. The basal cells are situated adjacent to the basal lamina and distributed throughout the epithelium. The basal cells are assumed to be the progenitors of the receptor and supporting cells (Yamamoto 1982, Zeiske et al. 1992). Increased mitotic figures have been observed in the basal region in a reconstituting epithelium after degeneration (Evans et at. 1982). cNSCs of the non-sensory epithelium possess numerous cilia that help in ventilating the olfactory chamber. Mucous cell secretes mucus to protect the epithelium from mechanical abrasion.

\section{ACKNOWLEDGEMENTS}

This work was supported by the financial assistance (MRP F.3-118/2003 (SR)) of the University Grants Commission, New Delhi. The authors are grateful to the Head of the Department of Zoology, Visva-Bharati University, Santiniketan for providing necessary laboratory facilities. Thanks are due to Dr S. Chakraborti, USIC Burdwan University, for his kind help during SEM study.

\section{REFERENCES}

Bannister L.H., 1965. The fine structure of the olfactory surface of teleostean fishes. Quarterly Journal of Microscopical Science 106: 333-342.

Belanger R.M., Smith C.M., Corkum L.D., Zielinski B.S., 2003. Morphology and histochemistry of the peripheral olfactory organ in the round goby, Neogobius melanostomus (Teleostei: Gobiidae). Journal of Morphology 257: 62-71. 
Bertmar G., 1973. Ultrastructure of the olfactory mucosa in the homing Baltic Sea trout, Salmo trutta trutta. Marine Biology 19: $74-88$.

Døving K.B., Dubois-Dauphin M., Holley A., Jourdan F., 1977. Functional anatomy of the olfactory organ of fish and the ciliary mechanism of water transport. Acta Zoologica $\mathbf{5 8}$ : 245-255.

Erickson J.R., Caprio J., 1984. The spatial distribution of ciliated and microvillous olfactory receptor neurons in the channel catfish is not matched by a differential specificity to amino acids and bile salt stimuli. Chemical Senses 9: 127-141.

Evans R.E., Zielinski B., Hara T.J., 1982. Development and regeneration of the olfactory organ in rainbow trout. pp. 15-37. In: Hara T.J. (ed.) Chemoreception in fishes. Elsevier, Amsterdam.

Farbman A.I., 2000. Cell biology of olfactory epithelium. pp.131-158. In: Finger T.E. Silver W.L., Restrepo D. (eds.) The neurobiology of taste and smell. Wiley, New York.

Fisher J.W., Mattie D.R., Paulos L.H., Helton C.D., 1984. Surface morphology of bluegill olfactory lamellae. Transactions of the American Microscopical Society 103: 93-97.

Hansen A., Finger T.E., 2000. Phyletic distribution of crypt type olfactory receptor neurons in fishes. Brain, Behavior and Evolution 55: 100-110.

Hansen A., Rolen S.H., Anderson K., Morita Y., Caprio J., Finger T.E., 2003. Correlation between olfactory receptor cell type and function in the channel catfish. Journal of Neuroscience 23 (28): 9328-9339.

Hara T.J., 1975. Olfaction in fish. Progress in Neurobiolology 5: 271-335.

Hara T.J., 1992. Mechanism of olfaction. pp. 150-170. In: Hara T.J. (ed.) Fish chemoreception. Chapman and Hall, London.

Hara T.J., 1993. Chemoreception. pp 191-218. In: Evans D.H. (ed.) The physiology of fishes. CRC Press, Boca Raton, FL.

Hara T.J., Sveinsson T, Evans R.E., Klaprat D.A., 1993. Morphological and functional characteristics of the olfactory and gustatory organs of three Salvelinus species. Canadian Journal of Zoology 71: 414-423.

Hara T.J., Zielinski B., 1989. Structural and functional development of the olfactory organ in teleosts. Transactions of the American Microscopical Society 118: 183-194.

Hernádi L., 1993. Fine structural characterization of olfactory epithelium and its response to divalent cation $\mathrm{Cd}_{2}{ }^{+}$in the fish Alburnus alburnus (Teleostei, Cyprinidae): A scanning and transmission electron microscopic study. Neurobiology 1 (1): 11-31.

Ichikawa M., Ueda K., 1977. Fine structure of the olfactory epithelium in the goldfish, Carassius auratus: A study of ret- rograde degeneration. Cell and Tissue Research 183: 445-455.

Kapoor A.S., Ojha P.P., 1972. Studies on ventilation of the olfactory chambers of fishes with a critical reevaluation of the role of accessory nasal sacs. Archives de Biologie 83: $167-178$.

Lowe G.A., Macleod M.K., 1974. The ultrastructural organization of olfactory epithelium of two species of gadoid fish. Journal of Fish Biology 7: 529-532.

Mana R.R., Kawamura G., 2002. A comparative study on morphological differences in the olfactory system of red sea bream (Pagrus major) and black sea bream (Acanthopagrus schlegeli) from wild and cultured stocks. Aquaculture 209: 285-306.

Muller J.F., Marc R.E., 1984. Three distinct morphological classes of receptor in fish olfactory organs. Journal of Comparative Neurology 222: 482-495.

Sato K., Suzuki N., 2001. Whole cell response characteristics of ciliated and microvillous olfactory receptor neurons to amino acids, pheromone candidates and urine in rainbow trout. Chemical Senses 26: 1145-1156.

Thommesen G., 1983. Morphology, distribution, and specificity of olfactory receptor cells in salmonid fishes. Acta Physiologica Scandinavica 117: 241-249.

Yamamoto M., 1982. Comparative morphology of the peripheral olfactory organ in teleosts. pp.39-59. In: Hara T.J. (ed.) Chemoreception in fishes. Elsevier, Amsterdam.

Zeiske E., Kasumyan A., Bartsch P., Hansen A., 2003. Early development of the olfactory organ in sturgeons of the genus Acipenser: A comparative and electron microscopic study. Anatomy and Embryology 206: 357-372.

Zeiske E., Kux J., Melinkat R., 1976. Development of the olfactory organ of oviparous and viviparous cyprinodonts (Teleostei). Zeitschrift für Zoologische Systematik und Evolutionsforschung 14: 34-40.

Zeiske E., Theisen B., Breucker H., 1992. Structure, development and evolutionary aspects of the peripheral olfactory system. pp. 13-39. In: Hara T.J. (ed.) Fish chemoreception. Chapman and Hall, London.

Zeiske E., Theisen B., Gruber S.H., 1987. Functional morphology of the olfactory organ of two carcharhinid shark species. Canadian Journal of Zoology 65: 2406-2412.

Zielinski B., Hara T.J., 1988. Morphological and physiological development of olfactory receptor cells in rainbow trout (Salmo gairdneri) embryos. Journal of Comparative Neurology 271: 300-311. 